\title{
Seed Concepts in Architecture and Mathematics
}

\author{
Kim Williams ${ }^{1} \cdot$ Michael J. Ostwald $^{2}$
}

Published online: 9 May 2016

(c) Kim Williams Books, Turin 2016

\begin{abstract}
The Co-Editors-in-Chief of the Nexus Network Journal introduce the contents of vol. 18, no. 2 (2016).
\end{abstract}

Keywords Architectural design - Design concepts · Archaeoastronomy · Fractal dimensions · Gothic architecture - Traditional Iranian brick patterns · Golden Mean

Architecture never springs to the designer's mind unbidden. Underlying even the most abstract and unbuildable designs are ideas and processes that the designer uses as a platform and vehicle for constructing the design. If we are lucky, traces of those initial concepts are found in the final work, and can be recovered and reconstructed, even centuries later, to take us back to the starting point. If we think of such concepts as 'seeds' or 'stem cells', their recovery allows us to use them for new designs and new architectural expressions, and so makes it possible for us to engage in a dialogue with those who came before us. The research papers contained in this issue of the Nexus Network Journal, vol. 18, no. 2, are all concerned with the search for and verification of just such ideas and processes.

We begin with three papers on the most ancient of architectures. In 'Sirius and the design of the megalithic enclosures at Göbekli Tepe', Giulio Magli examines the design of the oldest known structures in stone, which date from the tenth millennium B.C., from the point of view of archaeoastronomy, in order to verify the

Kim Williams

kwb@kimwilliamsbooks.com

1 Kim Williams Books, Corso Regina Margherita, 72, 10153 Turin, Italy

2 School of Architecture and Built Environment, The University of Newcastle, University Drive, Callaghan, NSW 2308, Australia 
site's relationship to a then new, brilliant star. He asserts that the orientation of the structures might have (roughly) followed the precessional drift of the rising azimuth of Sirius. Moving some seven millennia forward to another great structure in stone, Douglas McKenzie's paper examines 'The Course Thicknesses of the Great Pyramid' in order to explain a puzzle: 'Why are there so many thick courses high up in the pyramid?' His aim is to demonstrate that the course thicknesses were planned, at least at the group level, so that before starting to lay the courses of that group, all of their thicknesses were known. The next paper, 'Oracular Functioning and Architecture of Five Ancient Apollo Temples through Archaeoastronomy: Novel Approach And Interpretation' by Belen Martin Castro, Ioannis Liritzis and Anne Nyquist takes another step forward in time to the temples of Delphi, Didyma, Hierapolis, Delos and Rhodes, which date to between the sixth and fifth centuries B.C. Here again the authors employ the techniques of archaeoastronomy in order to show that a lunar-solar-stellar configuration has been applied to all five of these temples dedicated to Apollo, who was related in mythology to the constellations of Lyra and Cygnus. (More about the aims and methods of archaeoastronomy can be found in Giulio Magli's recent book, reviewed in this same issue; see below.)

The next group of four papers takes us to more recent historical periods and places; two of them concern design processes, and two concern construction techniques. In 'A Study of the Roughness of Gothic Rose Windows', Albert Samper and Blas Herrera analyze fifteen rose windows from as many Gothic cathedrals in France, Italy and Spain using a modern concept, fractal dimensions, in order to determine if it is possible to speak of a characteristic fractal pattern. In 'Geometry of the Icosikaidigon in Orvieto Cathedral' by Josep Lluís i Ginovart, Albert Samper, Blas Herrera, Agustí Costa and Sergio Coll, the authors geometrically analyse the unusual rose window of the Cathedral of Orvieto, based on the 22-sided polygon that cannot be constructed with only compass and straightedge, to learn how the designer constructed this figure. Geometric constructions were useful not only during the design phase, but during the construction phase as well. One of the techniques used to direct construction was to etch full-scale drawings on flat surfaces, such as floors, at the actual construction site. One such drawing has been recently discovered in the Cathedral of Seville. In 'Geometric Working Drawing of a Gothic Tierceron Vault in Seville Cathedral', authors Francisco Pinto-Puerto and Alfonso Jiménez-Martín present, document and decipher this important and rare drawing of a vault. Building materials themselves often provided the modules and measurements for constructions. A prime example of this is brick, where shapes can directly affect the rules for placement, size and arrangement. In 'Geometry and Bonding Rules Position Analysis in the Formation of Traditional Iranian Architectural Brick Facades', Nima Valibeig and Hanieh Mohammadi present a detailed analysis of geometry and bonding in historical Iranian architecture, based on field work and interviews with brick masons.

The final two research papers in this issue bring us to our own era. In 'Algorithmic Design Paradigm Utilizing Cellular Automata for the Han-ok', Youngjin Lee and Seung Hyun Kim first define the spatial organization of the traditional Korean house, Han-ok, and then use the computational method known as cellular automata (CA), which can simulate the process of growth by describing a 
complex system based on simple rules. The aim is to modernize the traditional house form to accommodate today's life-style while maintaining the core spatial relationships. In 'Proportional Systems in Late-Modern Architecture: the Case of Alejandro de la Sota', Óscar del Castillo Sanchez analyzes the work of the Spanish architect in terms of proportional systems, noting especially a sympathy for the Golden Mean.

This issue of the NNJ contains two articles in our 'Geometer's Angle' column. As the title implies, this column is devoted to geometric constructions and procedures that are helpful to designers. In 'A Vitruvius Inspired Criterion for the Construction of Polygons', Leno Liberato Mascia examines three renditions of the Vitruvian Man to reveal techniques for constructing polygons. In 'Morphic Angles', Mike Vanderroost introduces the concept of so-called morphic angles based on the 'morphic numbers', that is, the golden ratio and Dom Hans van der Laan's plastic number.

We conclude this issue with three book reviews. Richard Talbot reviews Felipe Cucker's Manifold Mirrors: The Crossing Paths of the Arts and Mathematics, an examination of the rules, laws and mathematical principles underlying music, painting and other creative arts. Alessandra Capanna reviews Adriana Rossi's Melodie di Pietra, an in-depth analysis of the Catalonian cloister of San Cugat, near Barcelona, on the basis of musical notions and symbolism. Finally, Kim Williams reviews Archaeoastronomy: Introduction to the Science of Stars and Stones by Giulio Magli, an overview of this relatively new but rapidly developing science.

This issue takes us to a vast range of periods in various corners of the world. We thank all the authors included here for their fine contributions to our journal, and wish the reader well.

Kim Williams is the founder and Co-Editor-in-Chief of the Nexus Network Journal: Architecture and Mathematics. She also founded and directs the international conference series 'Nexus: Relationships Between Architecture and Mathematics'.

Michael J. Ostwald is Professor and Dean of Architecture at the University of Newcastle, Australia. He is a Visiting Professor at RMIT University and a Research Fellow at SIAL (Melbourne). He has held past academic positions in the USA and Hong Kong and worked for architectural practices in Australia, the UK and the USA. Michael has a PhD in architectural theory and history and a higher doctorate (DSc) in design mathematics. He is Co-Editor-in-Chief of the Nexus Network Journal: Architecture and Mathematics (Springer) and a member of the Editorial Boards of $A R Q$ (Cambridge) and Architectural Theory Review (Taylor \& Francis). 